\title{
The Failure of Foreign Policy Entrepreneurs in the Trump Administration
}

\author{
Roberta Haar \\ Maastricht University \\ roberta.haar@maastrichtuniversity.n1 \\ Lutz F. Krebs \\ Maastricht University • United Nations Univeristy \\ krebs@merit.unu.edu
}

DRAFT

August 29, 2019

Abstract

The relationship a president has with the heads of his departments is a defining characteristic of a presidency. Policy entrepreneurs require presidential support and political capital to increase the chances of policy success. This paper argues that Donald J. Trump has established a contractor presidency that is encumbered by a number of scenarios originally identified in Laffin's (1996) study of the policy failures of George H.W. Bush's administration.

This investigation begins by first presenting the contractor model as a possible presidential strategy, and then establishes that Trump has embraced the contractor presidency as his approach towards foreign policy. We then identify alternate scenarios for a failed contractor presidency and consider whether these explanations apply to Trump's version. We find that two of the five scenarios apply to Trump's unsuccessful foreign policy: lack of support for his appointed officials and the appointment of inexperienced loyalists. 


\section{Introduction}

One of the most important decisions a president makes soon after the election is what kind of relationship he or she will have with the heads of departments and agencies in his or her administration. Will he/she control cabinet officials or will the president give them autonomy? For example, Richard Nixon, Ronald Reagan and Barack Obama implemented a strategy of central oversight while both Bush presidents afforded their top officials greater policy latitude, allowing them, for example, to select their subordinates. In particular, the strategy that George H.W. Bush adopted with some of his key officials is described as a "contractor presidency," one that subcontracted policy and management to top executives, giving them considerable freedom (Laffin 1996). The public policy scholar Martin Laffin found that Bush specifically appointed three policy activists or entrepreneurs to two cabinet positions and one agency head. Through their activism Bush's entrepreneurs certainly improved the morale in their departments and agency. Their strong activist reputations further enhanced the expectations of good policy outcomes.

However, when it came to policy success the opposite was true. Thus, Laffin designed his research, in which he used a variety of documentary sources, to find out why policy developed by entrepreneurs in the Bush administration was much less satisfactory than what Bush had anticipated when he adopted the approach. Laffin discovered that in the end the level of innovation and the entrepreneurial spirit of the appointees did not matter because without presidential activism - without Bush spending his own political capital in backing his entrepreneurs-policy ultimately failed.

Laffin's 1996 analysis of what went wrong with these three policy entrepreneurs is informative as a comparison since Donald J. Trump also created a contractor presidency, which seems equally doomed to fail for similar reasons. When he became president, Trump had few strong policy commitments, no well-defined policy agenda in both foreign or domestic policy and a vague notion of transactional governing. Like Bush, Trump appointed policy entrepreneurs because he lacked the relevant policy expertise. However, unlike Bush, Trump appeared to have a special respect and admiration for strong character generals in the first part of his presidency (Kelly 2016, Haberman, Thrush and Baker 2017). As a result, this research focuses on the three generals who Trump afforded the most independence in the area of foreign policy in the first part of his presidency; two in the Executive Office of the President, namely Secretary of Defense General James Mattis and National Security Adviser General H.R. McMaster, and the White House Chief of Staff, General John Kelly.

In his 1996 analysis, Laffin identifies five scenarios (outlined on page 6) that might produce failure in a contractor presidency, with Bush's unwillingness to expend his own political power in 
backing his entrepreneurs being the most important element of defeat. The analysis below of the five scenarios in Trump's contractor presidency suggests two causal mechanisms for failure. Firstly, that Trump withheld crucial support of the relevant policy as put forth by the entrepreneurs and, secondly, that he insisted in appointing too many inexperienced loyalists as staff working for the entrepreneurs. The interplay between these causal factors and the document evidence of policy failure are further illustrated through two cases; namely, the preservation and strengthening of the United States' alliance system and the maintenance of sanctions on Russia. The case selection is determined by the importance of the policy and the levels of investment (in terms of time, energy and reputation) that the entrepreneurs expended in advancing policy that was independent of the president.

The consideration of the five scenarios employs a content analysis using the Nerws on the Web corpus (Davies 2013). For the period between 8 November 2016 (the day that Trump won the election) and 2 January 2019 (the final day that any of the three operatives held office in the Trump administration), 1,395 news reports were identified in the New York Times and the Washington Post that mentioned Trump in connection with search terms for the three policy entrepreneurs. ${ }^{1}$ The news reports were then reviewed manually for applicability and then coded for the type of interaction. ${ }^{2}$ In total, 130 source documents were coded for 16 types of interaction that were related to the five potential causes, which are examined below. Annex A provides a list of the codes and frequency of occurrence. The section "Diagnosing a Contractor Presidency" presents a preliminary overview of the evidence for each of the five potential causal factors. Additionally, qualitative process tracing is employed in the two case studies, which additionally illustrate the two causal mechanisms for failure in Trump's contractor presidency. Process tracing is a valuable way to document the causal sequence of events in a case study (Bennett and Checkel 2015, Collier, Brady and Seawright 2010, 2011).

Because not much research exists that explores the elements of a contractor presidency, this investigation begins by first presenting the contractor model as a possible strategy that presidents might adopt. It then establishes that Trump embraced the contractor presidency as an approach towards his foreign policy. The next step is to identify the alternate scenarios for a failed contractor presidency and consider whether these explanations apply to Trump's version. The

1 The restrictions inherent to Davies' (2013) corpus mean that after identification of a relevant article, the original source was retrieved from the New York Times or the Washington Post. This study always cites the original source.

2 De-selection criteria were misidentification of the policy operative, repetitions of previous reports without new details, news summaries (e.g. WaPo's Daily 202, NYT Monday News Briefing), opinion pieces instead of factual reporting, reports of typical activities by the operative without any indication of their interaction or relation with the White House; reports of early thinking on which no exchange of opinions had occurred at the time of reporting (e.g. Mattis' trial balloon regarding the potential provision of arms to Ukraine in late August 2017), personal episodes and biographic background and reports of infighting among administration staff that lacked Trump's clear preferences or involvement. 
subsequent case studies further demonstrate that two of the five possible explanations apply to Trump's unsuccessful foreign policy.

\section{Trump's Contractor Presidency}

Most research on the relationship between the president and his top officials focuses on the "administrative" presidency strategy, as it mirrors the historical trend whereby presidents tighten central control (Kagan 2001, Lewis 2009, Nathan 1975, Resh 2015). A first step in overcoming the scarcity of research considering what qualifies as a contractor presidency is to take into account the varied interpretations of the functions of policy entrepreneurs and the activities that they might engage in (Roberts and King 1991). Entrepreneurial activities may include: to advocate new ideas and to develop proposals; to define and reframe problems; to specify policy alternatives; to mobilize public opinion; and to help set the decision-making agenda (Kingdon 1995; Polsby 1984). The three entrepreneurs considered in this study engaged in all of these activities, with decision-making power nominally placed in their hands. Entrepreneurial actors also build coalitions of supporters in order to secure policy outcomes, which the three entrepreneurs also attempted.

All three also believed they were policy entrepreneurs. For example, Kelly made numerous public statements that he believed that strong, independent leadership was essential in making progress in his work. One typical example is found in his confirmation testimony, where Kelly said Trump choose him because he "needed the kind of leadership, managerial and organization skills, and the willingness to make tough decisions that I exhibited during my career of military service" (Kelly 2016).

Undoubtedly, the placing of a strong policy entrepreneur was clearly the idea behind Mattis' selection as Secretary of Defense. Upon his appointment, Trump gave Mattis more latitude than any other executive, especially with policy regarding Afghanistan, Iraq, Syria and all of Southwest Asia (Gordon 2017). For instance, in a significant break from Obama's administrative presidency, which tightly controlled the use of missile strikes as a foreign policy instrument, Trump quickly approved Mattis' plan to fire sea-launched cruise missiles to punish Bashar al-Assad's use of chemical weapons on Syrian civilians. Soon after his easy confirmation process (in which even Senator Elizabeth Warren, said, "We're counting on you"), Mattis also acted independently in conducting trips to Asia, the Middle East and Europe to reassure allies (U.S. Senate Armed Services Committee 2017a).

Three U.S. strategic planning documents, that came out in December 2017 and January 2018, further clearly point to the generals' autonomy in formulating foreign and security policy. In a major speech presenting the administration's National Defense Strategy (NDS), Mattis made clear that he and McMaster were its authors and that it reflected their concerns about future 
threats to America, including elevating Russia as a main threat (U.S. Department of Defense 2018b, Wormuth 2018). Although Trump presented the second document, the National Security Strategy (NSS) in a December 2017 speech, he also appeared not to know its contents (Brands 2018b, White House 2017). The NSS, which was written by McMaster and senior National Security Council (NSC) staffer Nadia Schadlow, restated America's commitment to its strategic partners, rejected isolationism and reaffirmed America's broader role overseas. The third document is the January 2018 Nuclear Posture Review (NPR), which included the new goals to acquire low-yield tactical nuclear weapons as a direct response to Russia's announcement to develop similar nuclear options (U.S. Department of Defense. 2018a). Mattis emphasized the development of low-yield nuclear weapons in the NPR because he wanted the U.S. nuclear posture to remain a credible deterrent in relation to Russia's modernizing arsenal. Together the three documents present policies that disagree with Trump's inclination towards neo-isolationism and cultivating a personal relationship with Russian President Vladimir Putin.

Policy related to Afghanistan is another example of all three generals' capacity to develop a plan that was different from any ideas voiced by the president as well as policy that was dissimilar from the previous administration. Although he initially rejected his entrepreneurs' plan for Afghanistan, by the fall of 2017 Trump fully accepted it, which included a massive increase in offensive air power support and a large-scale troop expansion. Mattis further succeeded in shifting authorization of the increased troop numbers to the Pentagon from the White House (Gordon 2017, U.S. Senate Armed Services Committee 2017b, Ryan and Jaffe 2017). This was a major shift from the Obama administration's more administrative presidency practice of tightly controlling the decisions on military troops, a practice that led critics to charge that Obama was micromanaging the war in Afghanistan (Gates 2014).

In another significant change from Obama, Mattis gave broader authority to officers in the field to call for airstrikes against the Taliban. Trump accepted these changes despite the fact they went against his campaign stance on Afghanistan and the viewpoint of his then Chief Strategist Steven Bannon (Nakamura and Phillip 2017). To overcome Bannon's loyalist viewpoint, in midAugust 2017, Kelly, McMaster and Mattis planned a Camp David national security retreat to discuss policy in Afghanistan without Bannon. Although Trump gave Mattis the power to decide troop increases on his own, Mattis wisely refused to act without explicit authorization from the president.

The informal nature of Trumps' directives (most emanating from his Twitter feed) also allowed the three officials to often simply ignore his instructions. For example, when asked about Trump's tweet calling North Korean leader Kim Jong Un "short and fat," Kelly shrugged and said, "believe or not-I don't follow his tweets" (Bender 2017). In another instance, Mattis quickly rebuffed Trump's assertion at CIA headquarters in January 2017 that America might take 
Iraqi oil as compensation for U.S. efforts in the country (Stewart 2017). Mattis also ignored Trump's attempt to reverse Obama's 2016 Presidential Memorandum on Climate Change and National Security, which was related to threats to U.S. naval facilities because of rising sea levels and other effects of global warming on the military (Flavelle and Bain 2017 ).

The corpus shows a number of instances in which the policy entrepreneurs actively resisted implementing Trump's policy proposals within their areas of influence. For example, Mattis worked with Republicans in Congress to avoid a ban on transgender people in the military while Kelly slow-walked its implementation (Hirschfeld Davis and Cooper 2017, Kelly 2017a). Kelly and McMaster delayed the U.S. withdrawal from the Iran nuclear deal and the attempt to declare China a currency manipulator (Baker 2017a). Mattis further repeatedly attempted to soften the administrations' stance on trade (Swanson 2018). Kelly's statements upon his departure from the White House show how central key policy entrepreneurs considered their resistance to Trump's policies: "in his Los Angeles Times interview, Mr. Kelly suggested his tenure should be judged on the actions that Mr. Trump did not engage in, as opposed to the ones he did" (Haberman 2018).

\section{Five Alternate Explanations for Failure and What Constitutes Failure}

Just as there is a scarcity of research identifying what qualifies as a contractor presidency, so too is there a lack of research outlining what constitutes a poorly functioning contractor presidency. In his 1996 article, Laffin identifies five scenarios that might produce failure:

1. the entrepreneurs themselves could be poorly functioning bureaucratic and political performers;

2. the president's strategy in practice is more akin to an administrative presidency, with the president making excessive attempts to throttle policy initiatives;

3. the president might insist on appointing too many inexperienced loyalists, whose devotion lies outside the department or agency to which they are posted;

4. the permanent bureaucrats exhibit a resistance to any policy change based on their "careerists' self-interest or self-aggrandizement," and/or

5. the members of Congress attempt to defeat the policy emanating from the entrepreneurs. Before embarking on the analysis of the evidence supporting the five potential causes of failure in Trump's contractor presidency, it is important to establish what failure is. How do you recognize failure, which might have come about as the result of one of these five scenarios? Laffin detects failure in a contractor presidency when (1) there is limited policy achievement; (2) policy outcomes do not match the desired policy as proposed by the entrepreneur; and (3) there is disorganized and confusing decision-making within the policy area. 
Trump's contractor presidency failed on all three output levels, which the two cases studies further document (Brands 2018a, Brands 2018c, Cohen 2018, Goldsmith 2017, Patrick 2018, Sestanovich 2017). For instance, in both cases, U.S. policy suffered from a debilitating credibility gap between the stated policy and what the president said and did. In the first case, the entrepreneurs worked diligently to preserve and strengthen the United States' alliance system, yet, after a year, it was clear that they did not succeed (NATO official 2018). Even Trump's point that European NATO members ought to spend more on defense failed. Trump's amplified toxicity in Europe after his summer 2017 visit resulted in European leaders shifting away from any pledges to increase defense spending lest they appear to be kowtowing to Trump's demands (Gramer 2017).

On the contrary, America's trustworthiness and reputation greatly declined in Trump's first year as president. According to the 2018 Report on Rating World Leaders by Gallup, "Portugal, Belgium, Norway and Canada led declines worldwide, with approval ratings of U.S. leadership dropping 40 points or more in each country" (Ray 2018). Perhaps the most damming indication that U.S. foreign policy failed is The Bulletin of Atomic Scientists moving their Doomsday Clock the closest it had been to "midnight" since 1953, to reflect the geopolitical tensions in early 2018. Having 15 Nobel Laureates move their analysis of whether or not humanity is in danger of a nuclear holocaust back to where it was at the height of the Cold War, to a time when the Soviet Union had just tested its first hydrogen bomb, suggests failure (Bulletin of the Atomic Scientists 2018).

Evidence for the third indicator of failure included the administration's confusing, even contradictory measures toward Russia, highlighted by the tension between loyalists and entrepreneurs. The Trump administration gained a global reputation that it was unreliable, temperamental and even deceitful. Trust in the U.S. at the end of Trump's first year in office, was at an all-time low (Cohen 2018, NPR/PBS NewsHour/Marist poll). As former NATO deputy Secretary-General Alexander Vershbow pointed out, "For Europe, America will now always be the country that elected Donald Trump" (De Luce, Gramer and Tamkin 2018).

\section{Diagnosing a Contractor Presidency}

This section continues with an initial overview of the evidence supporting the five potential causes of failure of Trump's contractor presidency, with an integration of the coded interactions, followed by an investigation of two case studies via process tracing.

\section{Poorly-functioning Policy Entrepreneurs}

The first of the five scenarios that Laffin delineates that might produce failure is that the entrepreneurs themselves are poorly functioning bureaucratic and political performers. While it is true that all three generals were not outright politicians, they all were respected for their work 
in the military's bureaucracy before they were appointed to their positions. For example, Mattis, the most independent and the most politically safe of the three entrepreneurs, was a former NATO Supreme Allied Commander and one of the U.S. military's leading intellectuals (Sestanovich 2017). The former four-star general was well read and was an able, clever commander in the Iraq and Afghanistan wars. Mattis' appointment as the Defense chief was key evidence to Republicans early on that a more traditional foreign policy was forthcoming.

Similar to Mattis, McMaster was a widely respected military scholar, with a reputation for telling the truth (Braniff 2017, Kroenig 2017, Sestanovich 2017, Wright and Herb 2017). McMaster's appointment to the NSC marked him as the first active-duty appointment since Ronald Reagan appointed Colin Powell to be the National Security Adviser (NSA). At the time of his appointment, he was a three-star general, a graduate of West Point, had earned a $\mathrm{PhD}$ in military history and had authored a best-selling book about the failures of leadership during the Vietnam War. The book, entitled Dereliction of Duty, became required reading in the U.S. military in the late 1990s because of its insights in misperceptions in war. His record in Operation Desert Storm in Iraq also led to the inclusion of his counterinsurgency tactics in the Army Counterinsurgency Field Manual, which he rewrote with General David Petraeus. McMaster's thoughtful views on security and defense meant that the foreign-policy establishment was extremely pleased about his appointment. Michael O'Hanlon of the Brookings Institution even said that McMaster was "quite possibly the single most talented 3-star in U.S. military history" (Wright and Herb 2017).

However, such accolades also meant that America First devotees were against the general from the start and unlike Mattis, whose position enjoyed more political security, they worked hard to oust McMaster (Brannen 2017, Gray 2017a). This tension meant that of the three generals, McMaster had the poorest relationship with Trump, who had wanted to hire retired Vice Admiral Bob Harward to be his new NSA. However, Harward withdrew his name because he was not given assurances that he would be able to select his own staff and have autonomy from Trump's key political advisers in the White House (Wright and Herb 2017). Whatever the obstacles against him, the evidence is that McMaster improved the functioning of the NSC considerably over his immediate predecessor (Braniff 2017, Brannen 2017, McLaughlin 2017).

Kelly, a four-star general, was Chief at Homeland Security before moving unexpectedly to the White House in late July 2017. Kelly and Mattis were also friends, with each recommending the other to Trump in November 2016 as a possible Secretary of Defense. Soon after he arrived in the White House, Kelly forged a close partnership with both Mattis and McMaster in order to realize their shared policy goals. For his part, Kelly was also a highly respected former Marine general, who served as a senior military assistant to Secretaries of Defense Robert Gates and 
Leon Panetta and who promised to speak "truth to power" during his confirmation process (Abrams 2017, Kelly 2016).

Of the three generals, Kelly was the closet to Trump ideologically, as evidenced by the zeal that he enacted Trump's tough immigration policy while heading the Department of Homeland Security (DHS) (Trump 2017e). Indeed, Kelly's leadership qualities at DHS is why Trump picked him to be Chief of Staff and why Kelly was initially empowered to bring control to a chaotic West Wing (Bender 2017, Haberman, Thrush and Baker 2017). Although Kelly approached his work in the White House with determination, in fact, working 14-hour days to impose order, he had only marginal success at curbing the president's tweets (Bender 2017). On the one hand, Kelly's failure to contain the more negative characteristics of the president could be a factor in explaining the administration's failed foreign policy. On the other hand, since the president must be held more accountable for his personality, which his appointees found difficult to restrain, culpability should largely rest with the president himself.

Additionally, the corpus of reporting does not contain any indications of major policy mistakes caused by any of the three individually. Instead, it shows evidence of their functioning as typical policy entrepreneurs. Their arrivals were overwhelmingly hailed as a welcome injection of policy experience. Moreover, their influence was expected to be moderating and normalizing, with all three entrepreneurs initially living up to these expectations (Tumulty 2016, Tennis 2017). Examples of a moderating influence include steering the administration away from controversy and calming international allies and opponents, thereby retaining political capital (Birnbaum and Parker 2017, Lamothe 2017). The New York Times states clearly that "the structure [Mr. Kelly] has established [as Chief of Staff] resembles that of previous presidents" (Baker 2017a). The level of experience amassed by Kelly, Mattis and McMaster and their traditional conduct in office suggests that the poor functioning of policy entrepreneurs is not a likely scenario for Trump's failed contractor presidency.

\section{Trump's Contradictions}

Laffin's second causal factor is an attempt by the president to undermine or throttle policy proposals by his own entrepreneurs. The corpus shows a number of examples of the president along with close advisers attempting to implement policies without any form of consultation with the relevant departments: such as the executive order aimed at re-opening CIA black sites (Miller 2017); the administration's first travel ban (Rein and Eilperin 2017); McMaster's struggle to remove Bannon from the NSC (Costa and Phillip 2017); son-in-law Jared Kushner's informal talks with Russia (Rucker 2017); the ban on transgender people serving in the military (Hirschfeld Davis and Cooper 2017); and, Trump's threatening rhetoric towards North Korea (Baker and Harris 2017). 
During the timeframe under investigation, the president often exhibited a passive-aggressive behavior and a tendency to agree with the last person with whom he spoke (Allin 2017, Chong and Wittes 2017, Cohen 2017, Glasser and Kruse 2016, Goldsmith 2017, McAdams 2016, Visser, Book and Volk 2017, Wolf 2017). In this behavior, Trump's personality appeared to be a factor, with Visser et al finding that he scored "exceptionally low' on Honesty-Humility and Agreeableness, 'very low' on Emotionality, and 'low' on Conscientiousness. These results suggest that Trump's public persona most closely resembles the Dark Triad traits of being both narcissistic and psychopathic" (2017).

The second component of Trump's character, that he is easily suggestible, is one reason why Kelly was brought on board to replace Reince Priebus. When Kelly moved to the White House, he immediately tried to restrict and control both who saw the president and what information was given to him (Bender 2017, Kelly 2018). In this task, he joined McMaster, who also tried to control information from loyalists like Bannon and staff appointed by former NSA Michael Flynn. Mattis further contributed to the task of containing the president; in February 2017, the Associated Press reported that he and Kelly made an agreement after the inauguration that one of them should remain in the U.S. to monitor Trump at all times (Salama and Pace 2017). It should be noted that monitoring Trump was no small task. General Kelly's description of working for Trump included statements that it is the "toughest" and "most important job of his life," which he thought was more difficult than being a combatant commander in Iraq (Kelly 2017b, Kelly 2018). General Kelly's struggle spills over into the next causal factor identified by Laffin that the president might insist on appointing too many inexperienced loyalists.

\section{Loyalty Before Competence}

To emphasize the importance of loyalty, Laffin quotes Ronald Reagan's Secretary of Defense, Frank Carlucci, who said, "If you don't get your own people in place, you are going to end up a one-armed paper hanger" (1996). Successful entrepreneurial leaders rely heavily on their subcabinet-level appointments to translate their ideas into policy. Building a subcabinet team that has internalized a clear sense of mission gives cabinet officials considerable personal independence. The presence of loyalists, who have allegiances to the president, creates centrifugal forces. The pull of allegiances is likely to result in confused decision-making. Thus, the less cohesive a subcabinet team, the less likely an entrepreneurial executive will be able to develop and implement his or her policies.

Trump prevented his entrepreneurs from building their own teams. For instance, Mattis and Trump (at Bannon's behest) tussled over who would fill the undersecretary of defense for policy position, with Trump twice objecting to Mattis' picks. Mattis wanted to bring in staff from across the political spectrum while Trump was determined to appoint loyalists, in particular 
excluding the 122 Republican national-security experts who signed the "Never Trump" letter (Open Letter on Donald Trump From GOP National Security Leaders 2016).

McMaster also waged battles against Trump loyalists on issues related to trade, immigration and America's role in the world. One of McMaster's first steps as the NSA was to remove Bannon from the National Security Council but his clashes with loyalists ultimately led to a conflictive relationship between McMaster and the president. McMaster further clashed with Bannon and Kushner about whether or not to keep Flynn's personnel in the NSC (Costa and Phillip 2017). For their part, General Flynn's staff (labeled "Flynnstones") actively worked to push McMaster out of office with such tactics as an online campaign labeled \#FireMcMaster (Brannen 2017). McMaster also ran into difficulty in wanting to keep NSC holdovers from the Obama administration; staff that Bannon and Kushner wanted to fire (Gray 2017a). Gradually McMaster did place a number of his own staff in the NSC, who then spent much time and effort fighting Flynnstone stalwarts. The NSC Flynn-aligned holdovers also embarked on a leak campaign against McMaster, especially against his support for increasing the U.S. military presence in Afghanistan. In their attempt to tarnish McMaster with the failures of Afghanistan, Trump loyalists called the sixteen-year conflict "McMaster's War" (Everett and Dawsey 2017).

General Kelly also met with resistance when he tried to bring senior staff with him from the DHS. His preferred deputy chief of staff, Christian Marrone, was a Republican but had served in the Obama administration as the chief of staff to Homeland Security Secretary Jeh Johnson and was therefore rejected. The woman he did choose, Kirstjen Nielsen, known as an adept enforcer of Kelly's gatekeeping policy, found significant resistance when implementing Kelly's new disciplinary measures (Parker and Rucker 2017).

The corpus clearly shows that a pattern of dismissal over disagreements or perceived disloyalty was already visible when the administration was barely six months old (Baker and Haberman 2017). The impulse to remove disloyal staff persisted throughout the entire period under investigation. However, it is most noticeable with the first reports of Kelly's impending removal a mere 87 days into his tenure. Michael D. Shear writes that "If there was any doubt that Mr. Kelly faces a difficult balancing act, the chief's first task on Thursday was to beat back rumors that his own job is in immediate jeopardy. In doing so, he became the second top Trump official in a week to insist he is not about to be fired" (2017).

Because officials were chosen for their allegiance or their ability to flatter the president, many Trump appointees were quickly exposed as poorly suited for their jobs and as a result soon left or were fired. At the one-year mark of Trump's presidency, half of his high-level officials were either fired or had resigned, a record-setting rate of turnover (Dunn Tenpas 2018). According to Kathryn Dunn Tenpas, who wrote a Brookings Institution report on the Trump White House's "staggering" hiring and firing rate, "turnover creates disruption, it creates inefficiencies, it affects 
the morale" (quoted in Keith 2018). The high turnover in staff contributed to the chaotic manner that the White House functioned, which in turn led to more staff leaving and a further inability to develop sound, coherent policy.

\section{Bureaucrats that Resist}

Laffin's fourth scenario that might produce failure relates to the permanent bureaucrats who could exhibit a resistance to any policy based on their positions within their own bureaucracies. Perhaps it is an unusual situation, but the career civil servants were largely in agreement with the entrepreneurial executives who were put in charge of their departments and agency. This was especially true for policy in the two case studies because the three officials were advocating a course of action that adhered to the postwar consensus on U.S. foreign policy, which penetrated all bureaucracies of the executive branch (Boot 2018).

Civil servants did not trust Trump and found his campaign rhetoric to be ideologically hostile to deeply rooted views on a U.S.-led global order. Once in office, Trump challenged accepted norms and broke with diplomatic traditions, which further distanced him from the permanent bureaucracy (Goldsmith 2017, Michaels 2017). Thus, any bureaucratic intractability or drag on policy as promoted by the entrepreneurs was largely absent. There was little conscious obstructionism by individual careerists to policy promoted by the entrepreneurs.

On the contrary, career bureaucrats took action outside the normal networks by leaking documents or using their back-channel contacts within Congress in order to stop Trump, for example, in his attempts to remove sanctions on Russia. The career bureaucrats' support of the policy entrepreneurs led Trump loyalists to argue that a "deep state," a secret conspiracy of powerful permanent-government administrators, was obstructing Trump's agenda (Michaels 2017).

\section{A Congress that Resists}

The final scenario that Laffin identifies that might produce failure relates to the checks and balances of the legislative branch, whose members might attempt to defeat policy emanating from the entrepreneurs for their own reasons. An assertive Congress could stymie policy put forward by the entrepreneurs, particularly when the Executive branch and Congress are controlled by opposing parties. However, the corpus and the case studies clearly show that leading figures in Trump's own party disagreed with him just as much as members of the opposition differed with him. Meaning that although Trump enjoyed Republican majorities in both the House and the Senate (at least until November 2018), powerful members of Congress disagreed with him.

Instead, in the realm of foreign policy, Congress supported the three entrepreneurs over the president, almost from the beginning of Trump's presidency (Hirschfeld Davis \& Cooper 2017). 
Similar to the bureaucracies of the Executive branch, Congress advocated a line of policy that adhered to the postwar consensus on U.S. foreign policy, most obviously concerning the maintenance of alliances and policy towards Russia. For example, Republican Senators Lindsey Graham, Marco Rubio, Bob Corker and John McCain supported new crippling sanctions against Russia and Republican Majority Leader Mitch McConnell said he was against lifting sanctions. Contrary to what Trump advocated, Congress passed the Countering America's Adversaries Through Sanctions Act (CAATSA), which called for new sanctions against entities conducting business with Russia's defense and intelligence sectors and required Trump to compile a list of Russian names for possible further sanctions. Congress also supported the closing of Russian consulates suspected of espionage.

The discussion above points to two of the five possible explanations applying to Trump's failed contractor presidency. The following two case studies additionally show the interplay between the causal factors and the evidence of policy failure through process tracing historical facts.

\section{Case 1 - Maintaining America's Alliance System}

The first of the two policies that all three military men tried to shape is the preservation and strengthening of the United States' traditional alliance system. This policy stance is in clear disagreement to Trump's campaign rhetoric and instincts (Haass 2017). While it is hard to say that Trump holds a particular worldview, one constant that Trump has repeated over the years is that he believes that the U.S. is poorly served by the order that it built after WWII (Chandler 2017, Trump 2017a, 2017b, 2017g, 2017h, Wolf 2017).

Trump's transactional view of alliances certainly differed substantially from the three generals, who immediately attempted to offset their boss' statements concerning U.S. allies. For instance, Mattis made Seoul and Tokyo his first overseas stops in order to reassure worried allies that the U.S. remained a credible partner in the Asia-Pacific. In Tokyo in early February, Mattis said, "I want there to be no misunderstanding during this transition in Washington that we stand firmly, 100 percent shoulder-to-shoulder with the Japanese people" (U.S. Department of Defense 2017b). Later that same month in both Brussels and at the Munich Security Conference, Mattis moved to assure European allies that the U.S. would adhere to its alliance commitments (U.S. Department of Defense 2017c, U.S. Mission to the North Atlantic Treaty Organization 2017). Such words came as a relief to European leaders.

In a clear move to shape policy in a different direction from Trump's campaign rhetoric, Mattis and McMaster with the help of Secretary of State Rex Tillerson, inserted a strong commitment to European allies in the draft speech that Trump would give on his first overseas visit - an eight-day trip to the Middle East and Europe. However, when Trump gave the speech in Brussels he removed the reference to NATO's Article 5 (Trump 2017c). The last-minute change 
pointed to an early rupture inside the administration with the source of the deletion being Trump loyalist Stephen Miller.

Instead, Trump harangued his fellow alliance members in his speech and again in the subsequent closed-door meetings held at the new NATO headquarters (Gray 2017b, Shear, Landler and Kanter 2017). Trump's treatment of his fellow leaders caused pushback from both German Chancellor Angela Merkel and French President Emmanuel Macron, who both publicly criticized Trump shortly after the Brussels meeting (Calamur 2017). For instance, att the end of May, while campaigning in Munich, Merkel said that relying on the U.S. was "over to a certain extent. This is what I have experienced in the last few days" (Birnbaum and Noack 2017).

Realizing that the trip to NATO headquarters did not go as planned and that they had failed to keep Miller and Bannon away from the president, McMaster and Mattis moved to allay European offense and fears as soon as they got back to Washington, D.C. First, McMaster wrote a Wall Street Journal op-ed with National Economic Council Chief Gary Cohn that put a positive spin on Trump's trip. The article was entitled "America First doesn't mean America alone: We are asking a lot of our allies and partners. But in return the U.S. will once again be a true friend" (McMaster and Cohn 2017a). The article further emphasized a policy of fostering cooperation with allies and it praised Trump for reconfirming a U.S. commitment to Article 5, which he specifically had not done.

Second, McMaster gave a speech at the American Jewish Committee's Global Forum in which he praised Trump's visit to Saudi Arabia and to NATO headquarters. McMaster again insisted that Trump had reaffirmed America's unbreakable commitment to its European allies. Moreover, he said that many European leaders appreciated Trump's critical remarks on defense spending because, "They know it sometimes takes plain speaking to spur action" (Jaffe 2017). Third, McMaster did a keynote Q\&A session at a conference in Washington D.C. sponsored by the Center for a New American Security in which he said that doubts about American commitments to Article 5 were "manufactured" and described the relationship with Europe as involving "tough love," which was making the alliance "stronger" (McMaster 2017).

Fourth, after Trump's second trip to Europe in July, to attend the G20 Summit in Germany as well as additional meetings in Poland, McMaster wrote another op-ed with Cohn for the Nerw York Times, in which they emphasized the importance of American leadership, strengthening alliances and mutually advantageous trade. They restated Trump's words in Poland that "a strong Europe is a blessing to the West and the world" (McMaster and Cohn 2017b). However, such sentiments were in sharp contrast to Trump's support of European disintegration and praise for BREXIT, which was also on display. 
As indicated above, there is no better example of the differences between Trump and his policy entrepreneurs on alliances than the National Security Strategy, the National Defense Strategy and the Nuclear Posture Review, which all enunciated a desire to strengthen alliances. Mattis additionally pledged significant spending for European defense. For example, in June 2017, Mattis' requested $\$ 4.8$ billion for the 2018 European Reassurance Initiative (ERI) (Pellerin 2017). The ERI was first authorized in 2014, after Russia's invasion of Ukraine, with the goal to enhance NATO's deterrence capacities and to reemphasize U.S. commitments to the alliance. Mattis, with help from McMaster, also continued to apply pressure on Trump to state publicly that he supported Article 5. It was not until two weeks after he returned from his trip to Europe that Trump finally voiced such a reaffirmation (Baker 2017, Gramer 2017). When Trump read the statement, McMaster stayed close to him, carefully blocking Stephen Miller from view (Miller, Jaffe and Rucker 2017).

Despite these efforts by mostly Mattis and McMaster, doubts about America's commitment to the liberal world order featured prominently in the 2018 annual Munich Security Conference (16-18 February), where discussions focused on the contradictory messages coming from the Trump administration. Germany's Foreign Minister Sigmar Gabriel captured the frustration, saying, "We Germans in particular are perturbed when we look across the Atlantic. Is it deeds, is it words, is it tweets that we should look at to measure America?" (2018). McMaster met with Gabriel after his speech to reassure him that the U.S. was still committed to its allies, but the conference nonetheless ended on a contentious note (Schreck 2018).

The pattern was set early on: when the President needed to support his entrepreneurs' policy, he did not, preferring to rely on loyalists outside the official process. Over time, Trump replaced his entrepreneurs with devotees. Kelly was replaced with Mike Mulvaney, who indicated he wanted "to let Trump be Trump," McMaster was replaced by John Bolton, who regularly praised the president on Fox Nerws, and Mattis was replaced by Mike Pompeo, who as CIA director advocated pro-Trumpian positions even against the intelligence community that he led (Blake 2018, Parker, A., J. Dawsey and P. Rucker, C. D. Leonning 2018). Thus, the entrepreneurs did not see their policy achieved before they left office and allies were disturbed by the disorganized and confusing messages coming from the Trump administration. Trump's contractor strategy failed to bring about a credible foreign policy in relation to U.S. allies.

\section{Case 2 - Sanctions on Russia}

The second case equally illustrates that Trump's contractor presidency strategy met with great disappointment; indeed, the public displays of animosity between the president and his entrepreneurs on whether to maintain sanctions on Russia were highly unusual. Sanctions were placed on Russia in 2014 by the Obama administration via executive order to protest Russia's

annexation of Crimea, its military intervention in Ukraine and the downing of Malaysia Airlines 
Flight 17. Obama added further sanctions in response to Russian interference in the 2016 U.S. elections, specifically targeting four Russian intelligence officers, two Russian intelligence services and three companies (Obama 2016). Obama also expelled 35 Russian diplomats and closed two compounds on U.S. soil that Russia used in its spy operations.

Trump and his first NSA Flynn immediately moved to undo these measures (DeYoung and Filipov 2017). Early on, it was also clear that Trump's views on Putin and Russia significantly contradicted the assessments expressed by the three generals (Trump 2016a; 2016b; 2017d). For instance, in his Senate confirmation hearings, Mattis said that Putin was trying to break the North Atlantic alliance and that the U.S. needed to take integrated steps against him (U.S. Senate Armed Services Committee 2017a). With regards to sanctions, Mattis said that they will "remain in place until Moscow reverses the actions that triggered them" (U.S. Department of Defense 2017d). In December 2017, Mattis also said that the Russians interfered in the U.S. elections (U.S. Department of Defense 2017a). Kelly agreed with this assessment; shortly after becoming Chief of Staff in July 2017, Kelly publicly said at the Aspen Security Forum that he stood by the U.S. intelligence community's conclusion that Russia tried to influence the election in Trump's favor.

It was also clear when Trump appointed McMaster as Flynn's replacement that he would disagree with the president on Russian sanctions (Braniff 2017; Wright and Herb 2017). In 2014, McMaster led a secret Army study that analyzed how the Army should adapt to Russian military efforts in Ukraine (Bender 2016). Moreover, before his February 2017 appointment, McMaster was the director of the Army Capabilities Integration Center where his job was to forecast future threats to the Army and then devise means to meet those threats. In this post, he was on the record as saying that in addition to China, Russia was the greatest security threat facing the U.S. (McMaster 2017).

The dynamics of these disparate views between Trump and his entrepreneurs mean that any critical discussions about Putin, Russia or sanctions took place outside Trump's hearing, with the daily brief often structured to avoid upsetting the president with negative news related to Russia (Miller, Jaffe and Rucker 2017). Trump also ignored McMaster's advice not to meet Foreign Minister Sergey Lavrov and Ambassador Sergey Kislyak in the Oval Office in May 2017. Trump set up the meeting after a phone call with Putin in which Putin specifically requested it. Obama had refused to meet with Lavrov since 2013 (Glasser 2017). In the meeting, Trump volunteered that he fired FBI Director James Comey because of an investigation into Russia meddling in the 2016 campaign and he shared highly classified intelligence from an Israeli counterterrorism operative (Apuzzo, Haberman and Rosenberg 2017).

Trump further tried to go around the three generals through Kushner, who although was inexperienced in foreign policy was in line with the president's view on Russia. During Trump's 
May 2017 foreign trip it emerged that Kushner had discussed the possibility of setting up a secret and secure communications channel with the Kremlin (Rucker 2017). Shortly after this, at the G20 summit in Germany, when Trump and Putin met again, the deep divisions within the administration became publicly apparent (Salama 2017). McMaster again advised against holding an official bilateral meeting with Putin and, as a result, he refused to attend the meeting. Not only did the meeting lapse for more than two hours, but a Kremlin interpreter was the only other person present and Trump announced after it the possibility of a cybersecurity initiative with Russia, which was subsequently rejected by Congress.

Not only did Congress reject Trump's proposals, but congressional leaders also supported the generals' views on sanctions. Members of Congress were alarmed by a series of activities carried out by Trump loyalists, which included: efforts at the Republican National Convention to rewrite the platform that called for maintaining or increasing sanctions against Russia; exertions by NSA Flynn to lift sanctions soon after taking office; and, efforts to return control over the two diplomatic compounds, the latter being a major grievance for Russia. After reports that Trump met Putin alone in Germany, alarmed congressional leaders worked with equally anxious bureaucrats to pass CAATSA with an overwhelming majority. This legislation codified Obama's executive order, blocked any efforts to roll back sanctions and applied new sanctions against entities conducting significant business with Russia's defense and intelligence sectors (Miller, Jaffe and Rucker 2017). Incorporated into the legislation was a stipulation that the executive branch must compile a list of names of well-connected Russians with links either to the Kremlin or within Putin's inner circle (Demirjian 2016).

Although Trump signed CAATSA into law, he said the legislation was "seriously flawed," throwing into doubt whether he would actually enforce it (Phillip and Demirjian 2017). Putin's reaction to the law was to expel 755 U.S. government employees and close two U.S. diplomatic properties. Rather than criticize Putin, Trump thanked him for saving taxpayers the task of paying their salaries. In time, Trump loyalists also did not fulfill the spirit of the CAATSA law. For example, on the day of the deadline that Congress has stipulated for new sanctions, Trump stalwarts informed Congress that the administration would not in fact add sanctions. Additionally, right before the midnight deadline for the list of names of well-connected Russians, loyalists in the Treasury Department submitted a copy and paste document of a list of staff taken from the Kremlin's own English-language webpages combined with a 2017 Forbes Magazine list of the 200 richest businesspersons in Russia (Forbes 2017; Major Staff and key officials 2018). Since the list included Putin's foes, the document was of limited use.

In his December 2017 speech introducing his administration's NSS, Trump also soft-pedaled differences between the U.S. and Russia. What Trump said was in sharp contrast with the contents of the NSS, which called out Russia for meddling in other countries' politics (White 
House 2017). Differences over U.S. policy towards Russia was also on display at the 2018 annual Munich Security Conference. During the first day of the conference, Special Counsel Robert Mueller released the names of thirteen Russians who were personally involved in a hacking and propaganda campaign aimed at undermining the U.S. electoral process. The charges resulted in an acrimonious interchange between Russians attending the conference and McMaster, who also gave a speech at the conference. Like Kelly and Mattis, McMaster said he believed that the Kremlin tried to influence the 2016 U.S. election, stating that he thought the evidence was “incontrovertible" (Dawsey and Rucker 2018). Trump's subsequent public scolding of his NSA led to speculation that McMaster was about to be fired.

After a little over year into the administration, Trump and his key policy entrepreneurs were at loggerheads over sanctions on Russia. The result was that conflict with Russia was more likely after Trump's first year in office than at any time in the last twenty years (Dunford 2017, Mercier 2017, Strategic Foresight Analysis Report 2017). As Eliot Cohen commented, “[t]he curious tension between the president's sympathetic rhetoric and his administration's more hostile actions has increased the risk that a contemptuous and irritated Russia will poke back in eastern Europe" (Cohen 2018). Evidently, policy outcomes did not match the desired policy as proposed by Trump's entrepreneurs meaning that Trump's contractor strategy failed.

\section{Conclusion}

This research has two goals. First, it presents a greater understanding of the failures of Trump's first year in office, which was one of the messiest in the history of American foreign policy. Trump did not prepare to be elected president. Thus, when the time came to choose individuals to fill important foreign policy posts, Trump chose capable top executives and he gave them considerable freedom to make policy. Trump adopted a contractor presidency strategy as a way to augment his policy-making shortcomings.

Still, this did not mean that Trump supported the entrepreneurs that he appointed. The analysis of the five scenarios and the investigation of two case studies indicate that the causal mechanisms for failure in Trump's contractor presidency are, firstly, that the president withheld crucial support of the relevant policy as put forth by his entrepreneurs, often undermining and sabotaging their best efforts. And, secondly, that he appointed too many inexperienced loyalists, whose goal was to undermine their department and agency heads.

The second goal of this study is to overcome the lack of research on contractor presidencies. In the last few decades, most investigations on the relationship between the president and his key officials focused on the administrative presidency strategy because it reflected the historical trend whereby presidents tighten central control over their policy-making agenda. In an era of antiestablishment fervor, in which voters choose the candidate promising to shake-up Washington- 
with voters choosing the insurgent — the contractor presidency may become more relevant. This research thus endeavors to consider what activities and relationships qualify as a contractor presidency and what explains possible failures and even successes. The analysis incorporates the varied interpretations of the functions of policy entrepreneurs and the actions that they might engage in.

Finally, the foreign policy failures of Trump's contractor presidency reveal how misguided Republicans were that Trump was either trainable or that the party could install enough adults in leadership positions that a conventional Republican foreign policy would emerge. Republicans who thought that they could maneuver Trump should have looked back to the last time a Republican president handed over policy making to entrepreneurs in his administration. In the realm of domestic policy, the contractor presidency model failed for George H. W. Bush. Just as Bush's relationship with his entrepreneurs led to policy failure, Trump's contradicting relationship with his entrepreneurs also resulted in policy failure. 


\section{References}

- Abrams, E. 2017. Trump the Traditionalist. Foreign Affairs 96: 10-16.

- Allin, D. H. 2017. President Trump. Survival 58: 237-248.

- Apuzzo, M., M. Haberman and M. Rosenberg. 2017. Trump Told Russians That Firing 'Nut Job' Comey Eased Pressure From Investigation. New York Times May 19.

- Baker, P. 2017a. Sage Advice From the 'Gold Standard' of White House Chiefs of Staff. New York Times July 30.

- Baker, P. 2017b. For Trump, a Year of Reinventing the Presidency. New York Times Dec. 31.

- Baker, P. and G. Harris. 2017. Deep Divisions Emerge in Trump Administration as North Korea Threatens War. New York Times Aug. 9.

- Baker, P. and M. Haberman. 2017. Anthony Scaramucci's Uncensored Rant: Foul Words and Threats to Have Priebus Fired. New York Times July 27.

- Bender, B. 2016. The Secret U.S. Army Study That Targets Moscow. Politico Magazine April 14.

- Bender, M. C. 2017. Trump Finds Loopholes in Chief of Staff's New Regime. Wall Street Journal December 3.

- Bennett, A. and J. T. Checkel. 2015. Process Tracing: From Metaphor to Analytic Tool. Cambridge UK: Cambridge University Press.

- Birnbaum, M. and A. Parker. 2017. In trip to Brussels, Pence tries soothing anxious leaders with pro-E.U. message. Washington Post Feb. 20.

- Birnbaum, M. and R. Noack. 2017. Merkel: Europe must go it alone Washington Post May 29, A10.

- Blake, A. 2018. Trump is getting closer to a Cabinet full of yes men. Washington Post December 21.

- Boot, M. 2018. Trump Security Strategy a Study in Contrasts. Council on Foreign Relations. Retrieved January 31.

- Brands, H. 2018a. American Grand Strategy in the Age of Trump. Washington, D.C.: Brookings Institution Press. 
- Brands, H. 2018b. If you Thought 2017 was Bad, Just Wait for 2018. Foreign Policy January 8.

- Brands, H. 2018c. The Unexceptional Superpower: American Grand Strategy in the Age of Trump. Survival 59: 7-40.

- Braniff, S. P. 2017. Trump's new national security adviser disagrees a lot with...Trump. Washington Post February 22.

- Brannen, K. 2017. The Knives Are Out for Lt. Gen. H.R. McMaster. Foreign Policy May 9.

- Bulletin of the Atomic Scientists. 2018. "It is 2 minutes to Midnight." https://thebulletin.org/timeline.

- Calamur, K. 2017. Merkel Urges 'Europe to Take our Fate Into Our Own Hands,' The Atlantic May 30.

- Chandler, A. 2017. Why Foreign Leaders Read Trump's 1990 Playboy Interview, The Atlantic.

- Chong, J. and B. Wittes. 2017. Foreign Policy August 28.

- Cohen, E. A. 2018. Trump's Lucky year. Foreign Affairs 97: 2-9.

- Collier, D., H. E. Brady and J. Seawright. 2011. A Sea Change in Political Methodology. Newsletter of the American Political Science Association 9: 1-20.

- Collier, D., H. E. Brady and J. Seawright. 2010. Outdated Views of Qualitative Methods: Time to Move On. Political Analysis 18:506-513, doi:10.1093/pan/mpq022.

- Cooper, H. 2018. Fraying Ties With Trump Put Jim Mattis's Fate in Doubt. New York Times Sept. 15.

- Costa, R. and A. Phillip. 2017. Stephen Bannon removed from National Security Council. Washington Post Apr. 5.

- Davies, M. 2013. “Corpus of News on the Web (NOW): 3+ billion words from 20 countries, updated every day." https://corpus.byu.edu/now/.

- Davies, M. 2019. “Limitations.” https://www.corpusdata.org/limitations.asp.

- Dawsey, J., and P. Rucker. 2018. Trump lashes out on Twitter at probe. Washington Post February 19, A01. 
- De Luce, D., R. Gramer and E. Tamkin. 2018. Trump's Shadow Hangs Over NATO. Foreign Policy January 29.

- Demirjian, K. 2016. Congressional push for sanctions against Russia could set up clash with Trump. Washington Post December 19, A13.

- DeYoung, K., and D. Filipov. 2017. Trump: It's 'very early' to discuss lifting sanctions on Russia. Washington Post January 28, A08.

- Dunford, J. F. 2017. Stenographic Transcript Before the Senate Armed Services Committee Nomination - Dunford. September 26.

- Dunn Tempas, K. 2018. Why is Trump's turnover higher than the 5 most recent presidents? Report Brookings Institution January 19.

- Everett, B. and J. Dawsey. 2017. Republicans resign themselves to Trump's scandals. Politico Magazine May 16.

- Flavelle, C. and B. Bain. 2017. Washington Bureaucrats Are Quietly Working to Undermine Trump's Agenda. Bloomberg Politics December 18.

- Forbes. 2017. http://www.forbes.ru/rating/342579-200-bogateyshih-biznesmenov-rossii2017\#all_rating.

- Gabriel, S. 2018. Rede von Außenminister Sigmar Gabriel bei der Münchner Sicherheitskonferenz. https://www.auswaertiges-amt.de/de/newsroom/rede-muenchnersicherheitskonferenz/1599848.

- Gates, Robert M. 2014. Duty. New York: Alfred A. Knopf.

- Glasser, S. 2017. Russia’s Oval Office Victory Dance. Politico Magazine May 10.

- Glasser, S., and M. Kruse. 2016. Trumpology: A Master Class. Politico Magazine.

- Goldsmith, J. 2017. Will Donald Trump Destroy the Presidency? The Atlantic October.

- Gordon, M. R. 2017. Trump Gives Mattis Authority to Send More Troops to Afghanistan. New York Times June 13.

- Gramer, R. 2017. Trump Discovers Article 5 After Disastrous NATO Visit. Foreign Policy June 9.

- Gray, R. 2017a. An NSC Staffer is Forced Out Over a Controversial Memo. The Atlantic August 2. 
- Gray, R. 2017b. Trump Declines to Affirm NATO’s Article 5. The Atlantic May 25.

- Haass, R. N. 2017. “Trump foreign policy has found its theme: The Withdrawal Doctrine. US has left/threatening to leave TPP, Paris accord, UNESCO, NAFTA, JCPOA" October 12. https://twitter.com/RichardHaass/status/918471381511229440.

- Haberman, M. 2018. Kelly, on His Way Out, Says Administration Long Ago Abandoned Idea of Concrete Wall. New York Times Dec. 30

- Haberman, M., G. Thrush and P. Baker. 2017. Inside Trump's Hour-by-hour Battle for Self-preservation. New York Times December 9.

- Hirschfeld Davis, J. and H. Cooper. 2017. Trump Says Transgender People Will Not Be Allowed in the Military. New York Times, July 26.

- Jaffe, G. 2017. McMaster praises president's trip. Washington Post June 4, A03.

- Kagan, E. 2001. Presidential Administration. Harvard Law Review 114: 2245-2385.

- Keith, T. 2018. Turnover In Trump's White House Is 'Record-Setting.' National Public Radio January 19.

- Kelly, J. 2017a. Homeland Security Confirmation Hearings. C-Span January 10

- Kelly, J. 2017b. Press Briefing by Press Secretary Sarah Sanders and Chief of Staff General John Kelly. The White House October 12.

- Kelly, J. 2016. U.S Senate Committee on Homeland Security and Governmental Affairs Pre-hearing Questionnaire Fore the Nomination of General John F. Kelly to be Secretary, Department of Homeland Security. December 28.

- Kelly, J. 2018. The White House chief of staff joins 'Special Report' for an exclusive interview. Fox News, January 17.

- Kingdon, J.W. 1995. Agendas, Alternatives, and Public Policies, 2nd ed. Boston: Little, Brown \& Company.

- Kroenig, M. 2017. The Case for Trump's Foreign Policy. Foreign Affairs 96: 30-34.

- Laffin, M. 1996. The President and the Subcontractors: The Role of Top Level Policy Entrepreneurs in the Bush Administration. Presidential Studies Quarterly 26: 550-566.

- Lamothe, D. 2017. Pentagon chief arrives in Singapore after Trump pulls out of Paris climate deal. Washington Post June 2. 
- Lewis, D. E. 2009. Revisiting the Administrative Presidency: Policy, Patronage, and Agency Competence. Presidential Studies Quarterly 39: 60-73.

- Major Staff and key officials 2018. http://en.kremlin.ru/structure/administration/members.

- Martin, J. and M, Landler. 2017. Bob Corker Says Trump's Recklessness Threatens 'World War III.' New York Times October 8.

- McAdams, D. P. 2016. The Mind of Donald Trump. The Atlantic May.

- McLaughlin, J. 2017. The Guerrilla Campaign Against McMaster Is Alive and Well. Foreign Policy December 14.

- McMaster, H.R. and G. D. Cohn. 2017a. America First Doesn't Mean America Alone. Wall Street Journal May 30.

- McMaster, H.R. and G. D. Cohn. 2017b. The Trump Vision for America Abroad. New York Times July 13.

- McMaster, H.R. 2017. "Keynote Address." Center for a New American Security June 28. https://www.cnas.org/publications/video/cnas-2017-keynote-address-by-ltg-h-rmomaster.

- Mercier, D. 2017. "Keynote Remarks, Opportunities and Challenges of a Complex Future: Launching ACT's 2017 Strategic Foresight Analysis Report.” Atlantic Council. November 17. https://www.youtube.com/watch?v=v1swdNX15Rc.

- Michaels, J. 2017. Trump and the 'Deep State:'The Government Strikes Back. Foreign Affairs 96: 52-56.

- Miller, G. 2017. White House draft order calls for review on use of CIA 'black site' prisons overseas. Washington Post Jan. 25.

- Miller, G., G. Jaffe and P. Rucker. 2017. How Trump's pursuit of Putin has left the U.S. vulnerable to the Russia threat. Washington Post December 15, A01.

- Nakamura, D. and A. Phillip. 2017. Troop increase planned in Afghan war. Washington Post August 22, A10.

- Nathan, R. P. 1975. The plot that failed: Nixon and the administrative presidency New York: Wiley. 
- Strategic Foresight Analysis Report. October 4, 2017.

http://www.act.nato.int/images/stories/media/doclibrary/171004_sfa_2017_report_hr.pdf

- NATO official. 2018. Interview Office of the Political Adviser JFC HQNATO Brunssum, The Netherlands. February 2.

- NPR/PBS NewsHour/Marist Poll Results. 2018. January 18. http://maristpoll.marist.edu/nprpbs-newshourmarist-poll-results-january-2018/.

- Obama, B. 2016. "Statement by the President on Actions in Response to Russian Malicious Cyber Activity and Harassment.” December 29. https://obamawhitehouse.archives.gov/the-press-office/2016/12/29/statement-presidentactions-response-russian-malicious-cyber-activity.

- “Open Letter on Donald Trump From GOP National Security Leaders." 2016. War on the Rocks March 2. https://warontherocks.com/2016/03/open-letter-on-donald-trumpfrom-gop-national-security-leaders/.

- Parker, A. and P. Rucker. 2017. Chafing over Kelly's style as he tames White House. Washington Post September 23, A01.

- Parker, A., J. Dawsey, and P. Rucker, C. D. Leonning. 2018. Trump plans to replace McMaster, maybe others. Washington Post March 16, A01.

- Patrick, S. 2018. How U.S. Allies Are Adapting to 'America First.' Foreign Affairs January 23.

- Pellerin, C. 2017. "2018 Budget Request for European Reassurance Initiative Grows to \$4.7 Billion." Department of Defense. June 1. https://www.defense.gov/News/Article/Article/1199828/2018-budget-request-foreuropean-reassurance-initiative-grows-to-47-billion/.

- Phillip, A. and K. Demirjian. 2017. Trump reluctantly signs Russia sanctions bill. Washington Post August 3, A01.

- Polsby, N. W. 1984. Political Innovation In America: The Politics of Policy Initiation. New Haven, Conn.: Yale University Press.

- Ray, J. 2018. "World's Approval of U.S. Leadership Drops to New Low.” Gallup Nerws. January 18. http://news.gallup.com/poll/225761/world-approval-leadership-drops-newlow.aspx. 
- Rein, L. and J. Eilperin. 2017. White House installs political aides at Cabinet agencies to be Trump's eyes and ears. Washington Post Mar. 19.

- Resh, W. 2015. Rethinking the Administrative Presidency: Trust, Intellectual Capital, and Appointee-Careerist Relations in the George W. Bush Administration. Baltimore, MD: Johns Hopkins University Press.

- Roberts, N. C. and P.J. King. 1991. Policy Entrepreneurs: Their Activity Structure and Function in the Policy Process. Journal of Public Administration Research and Theory 1: 147175.

- Rucker, P. 2017. Trump adviser: 'I would not be concerned' about a Russia back channel, irrespective of Kushner. Washington Post May 27.

- Ryan, M. and G. Jaffe. 2017. U.S. poised to ramp up Taliban fight. Washington Post May 9, A01.

- Salama, V. 2017. Trump's embrace of Russia making top advisers wary. AP Nerws July 20.

- Salama, V. and J. Pace. 2017. Trio of Military Men Gain Growing Influence with Trump. Associated Press February 23.

- Sestanovich, S. 2017. The Brilliant Incoherence of Trump's Foreign Policy. The Atlantic May.

- Shear, M. D. 2017. Trump's Chief of Staff, Speaking With Press, Walks a Verbal Tightrope. New York Times Oct. 12.

- Shear, M. D., M. Landler and J. Kanter. 2017. In NATO Speech, Trump is Vague About Mutual Defense Pledge. New York Times May 25.

- Schreck, C. 2018. 'We're In Trouble:' Rancor Rules At Munich Security Conference. Radio Free Europe February 18.

- Stewart, P. 2017. Trump's defense chief: 'We're not in Iraq to seize anybody's oil.' Reuters. February 20.

- Swanson, A. 2018. Trump to Impose Sweeping Steel and Aluminum Tariffs. New York Times March 1.

- Tennis, K. H. 2017. Trump's border wall ignores a long history of U.S. cooperation with Mexico. That's a problem. Washington Post Feb. 14. 
- Thrush, G. and Ma Haberman. 2017. Forceful Chief of Staff Grates on Trump, and the Feeling Is Mutual. New York Times Sept. 1.

- Trump, D. J. 2016a. "Donald Trump Speaks at AIPAC Policy Conference (3-21-16)." https://www.youtube.com/watch?v=obIa7ZIHzXE.

- Trump, D. J. 2016b. “Great move on delay (by V. Putin) - I always knew he was very smart!” December 30. https://twitter.com/realdonaldtrump/status/814919370711461890? lang=en.

- Trump, D. J. 2016c. "The new joke in town is that Russia leaked the disastrous DNC emails, which should never have been written (stupid), because Putin likes me." July 25. https://twitter.com/realdonaldtrump/status/757538729170964481?lang=en.

- Trump, D. J. 2017a. "Despite what you have heard from the FAKE NEWS, I had a GREAT meeting with German Chancellor Angela Merkel. Nevertheless, Germany owes....." March 18. https://twitter.com/realDonaldTrump/status/843088518339612673.

- Trump, D. J. 2017b. “The Inaugural Address.” January 20. https://www.whitehouse.gov/briefings-statements/the-inaugural-address/.

- Trump, D. J. 2017c. "President Trump NATO Summit Speech in Brussels, Belgium 5/25/2017." https://www.youtube.com/watch?v=NBSaNMGpKo0.

- Trump, D. J. 2017d. "Putin \& I discussed forming an impenetrable Cyber Security unit so that election hacking, \& many other negative things, will be guarded.."July 9. https://twitter.com/realDonaldTrump/status/884016887692234753).

- Trump, D. J. 2017e. "Remarks by President Trump After Swearing In General John Kelly as White House Chief of Staff.” The White House July 31.

- Trump, D. J. 2017f. Remarks by President Trump on the Administration's National Security Strategy. The White House December 18.

- Trump, D. J. 2017g. Remarks by President Trump to the $72^{\text {nd }}$ Session of the United Nations General Assembly. The White House September 19.

- Trump, D. J. 2017h. “...vast sums of money to NATO \& the United States must be paid more for the powerful, and very expensive, defense it provides to Germany!” March 18. https://twitter.com/realDonaldTrump/status/843090516283723776.

- Tumulty, K. 2016. “Trump backs away from some of his strident campaign promises.” Washington Post Nov. 22. 
- U.S. Department of Defense. 2017a. Off-Camera Media Availability with Secretary of Defense James Mattis. December 15.

- U.S. Department of Defense. 2018a. Nuclear Posture Review. February.

- U.S. Department of Defense. 2017b. Remarks by Secretary Mattis and Prime Minister Abe in Tokyo. February 3.

- U.S. Department of Defense. 2017c. Remarks by Secretary Mattis at the Munich Security Conference in Munich, Germany. February 17.

- U.S. Department of Defense. 2017d. Secretary of Defense James Mattis Remarks with President Petro Poroshenko. August 24.

- U.S. Department of Defense. 2018b. Summary of the 2018 National Defense Strategy, Sharpening the American Military's Competitive Edge.

- U.S. Mission to the North Atlantic Treaty Organization 2017. "Intervention by Secretary of Defense Mattis." February 15. https://nato.usmission.gov/february-15-2017intervention-secretary-defense-mattis-session-one-north-atlantic-council/.

- U.S. Senate Armed Services Committee. 2017a. Transcript Confirmation Hearing Mr. James N. Mattis to be Secretary of Defense. January 12.

- U.S. Senate Armed Services Committee. 2017b. Transcript Defense Budget Fiscal Year 2018. June 13.

- Visser, B. A., A. S. Book and A. A. Volk. 2017. Is Hillary dishonest and Donald narcissistic? A HEXACO analysis of the presidential candidates' public personas. Personality and Individual Differences 106: 281-286.

- Wolf, R. 2017. Donald Trump's Status-Driven Foreign Policy. Survival 59: 99-116.

- Wormuth, C. 2018. Can Mattis Succeed Where his Predecessors have Failed? Foreign Policy January 23.

- Wright, A. and J. Herb. 2017. Trump's new warrior-scholar. Politico Magazine February 20. 


\section{Annex A. Codes}

\section{Policy implementation}

- Assisting with policy implementation: policy entrepreneur is said to assist with the implementation of Trump's policies. 9 occurrences.

- Resisting policy implementation: policy entrepreneur is said to have worked to resist the implementation of Trump's policies. 13 occurrences.

\section{Consultation between policy entrepreneur and White House}

- Effort to consult: policy entrepreneur is said to have been consulted or involved by Trump or the White House. 3 occurrences.

- Lack of consultation/influence: policy entrepreneur is said not to have been consulted or to lack influence on relevant policy matters. 13 occurrences.

\section{One-sided influence of policy entrepreneur on Trump}

- Influence on world-view: policy entrepreneur is said to (attempt to) exert an influence on Trump's world view. 8 occurrences.

- Moderating influence: policy entrepreneur is said to have a moderating influence on Trump. 23 occurrences.

- Asserting control: policy entrepreneur is asserting control over a policy domain in opposition to Trump or White House staff. 2 occurrences.

- Public criticism: policy entrepreneur is said to have publicly criticized Trump. 3 occurrences.

\section{Agreement and disagreement}

- View agreement: policy entrepreneur is said to agree with the views of Trump. 18 occurrences.

- View disagreement: policy entrepreneur is said to disagree with the views of President Trump. 43 occurrences.

- Policy agreement: policy entrepreneur is said to agree with President Trump on a specific policy question. 11 occurrences.

- Policy disagreement: policy entrepreneur is said to disagree with President Trump on a specific policy question. 41 occurrences. 
Spin

- Calming PR: policy entrepreneur is said to have communicated a calming message in response to a more extreme view communicated by Trump. 24 occurrences.

- Escalating PR: policy entrepreneur is said to further escalate extreme messages by Trump. 3 occurrences.

\section{Potential for termination}

- Resignation: policy entrepreneur is said to be considering resigning from his post in the Trump administration. 9 occurrences.

- Dismissal: policy entrepreneur is said to be a candidate for dismissal. 9 occurrences. 